\title{
Correction to: Phytase Immobilization on Hydroxyapatite Nanoparticles Improves Its Properties for Use in Animal Feed
}

\author{
Thamara C. Coutinho ${ }^{1,2} \cdot$ Paulo W. Tardioli $^{2}$ - Cristiane S. Farinas ${ }^{1,2}$ \\ Published online: 25 October 2019 \\ C) Springer Science+Business Media, LLC, part of Springer Nature 2019
}

\section{Correction to: Applied Biochemistry and Biotechnology https://doi.org/10.1007/s12010-019-03116-9}

In the original version of this article, under Calculation of Immobilization Parameters heading, the presentation of the equations are incorrect. The correct presentation of the equations are given below:

\section{Calculation of immobilization parameters}

The percentage immobilization yield $(I Y)$ was calculated using the equation:

$$
I Y(\%)=1-\frac{\left[P_{\text {supernatant } 1}\right]+\left[P_{\text {supernatant } 2}\right]}{\left[P_{\text {control }}\right]} \times 100,
$$

where $P_{\text {supernatant } 1}$ and $P_{\text {supernatant } 2}\left(\mathrm{mg} \mathrm{mL}^{-1}\right)$ are the protein concentrations for supernatant 1 (obtained after the first wash) and supernatant 2 (obtained after the second wash), respectively, and $P_{\text {control }}\left(\mathrm{mg} \mathrm{mL}^{-1}\right)$ is the protein concentration for the control

The online version of the original article can be found at https://doi.org/10.1007/s12010-019-03116-9

Cristiane S. Farinas

cristiane.farinas@embrapa.br

Thamara C. Coutinho

thamaraccoutinho@gmail.com

Paulo W. Tardioli

pwtardioli@ufscar.br

1 Embrapa Instrumentation, Rua XV de Novembro 1452, Sao Carlos, SP 13560-970, Brazil

2 Graduate Program of Chemical Engineering, Federal University of São Carlos, Sao Carlos, SP 13565-905, Brazil 
(soluble enzyme). The enzymatic activity that was offered to the support $\left(A_{O f}\right)$ was calculated using the equation:

$$
A_{\text {of }}\left(\frac{I U}{g \text { support }}\right)=\frac{A_{\text {solubleenzyme }} \times \text { volume of enzyme offered }(\text { in } m L)}{\text { mass of support }(\text { in } g)} \text {, }
$$

where $A_{\text {soluble enzyme }}\left(\mathrm{IU} \mathrm{mL} \mathrm{m}^{-1}\right)$ is the activity of the free enzyme. The theoretically immobilized activity $\left(A_{T I}\right.$, in IU $\mathrm{g}^{-1}$ support) was obtained as the product of the activity offered to the support $\left(A_{O f}\right)$ and IY $\times 100^{-1}$. The recovered activity $(R A)$ of the immobilized enzyme was calculated as follows:

$$
R A(\%)={ }^{A_{D E}} / A_{\text {of }} \times 100,
$$

where $A_{D E}$ is the activity of the derivative (IU g ${ }^{-1}$ support).

Publisher's Note Springer Nature remains neutral with regard to jurisdictional claims in published maps and institutional affiliations. 